\title{
Problems of the implementation of the food self-sufficiency strategy
}

\author{
Fayaz Avkhadiev*, Farit Mukhametgaliev, Ilgizar Gainutdinov, Nail Asadullin and Marcel Khismatullin
}

Kazan State Agrarian University, Kazan, 420015, Russia

\begin{abstract}
The relevance of the topic of the article is caused by the need to study the level of agricultural production and the country's self-sufficiency with basic food products in the context of fierce competition in the world food market and sanctions from Western European countries and the United States. The purpose of the article is to identify trends in the implementation of the strategy of import substitution of food products and to determine the priorities for the development of the agricultural business in import and export activities. The article is devoted to a comprehensive study of the current state of food production and the development of priority directions for the effective functioning of enterprises of agricultural production and processing of agricultural raw materials in modern conditions of external and internal socio-political challenges and risks. The article defines the current state of food supply for the population of the country, identifies trends and priority strategic directions for implementing the policy of import substitution, and ensuring food security of the country suggests the need for an interconnected and balanced organization of import and export activities of agricultural enterprises. The theoretical provisions and practical recommendations proposed in the article allow solving the problem of stable self-sufficiency of the country with competitive food products and the transition to the implementation of an export-oriented strategy for the development of the agricultural sector of the economy.
\end{abstract}

\section{Introduction}

An important direction in achieving food security of the country is the self-provision of food products based on the development of the national agri-food complex. External and internal challenges that have arisen in connection with the sanctions restrictions require a revision of the directions of the food supply with the adjustment of the vector of state support towards the development of domestic subjects of the agrarian business. The priority directions of the development of the agri-food complex, first, presuppose a balanced development of agricultural sectors and the steady provision of increased growth rates of the volume indicators of agricultural raw materials, an increase in the capacity of the transfer industry, and regulation of the domestic food market. The global economic processes taking place in the world food market over the past seven years have contributed to Russia's transition to the implementation of an import substitution strategy aimed at meeting domestic food needs with food at affordable prices by developing the domestic agri-food business and minimizing import receipts of food products to the level determined by the Doctrine of Food Security of the Russian Federation [1,2]. The transition to a new strategy of self-sufficiency in food for the country's population gave a new impetus to the development of the agricultural sector of the economy, the results of which were increased state support for the implementation of targeted programs for the development of agriculture, the activation of agricultural business entities based on the diversification of spheres of activity, which led to a sustainable an increase in the production of agricultural products, and, accordingly, an increase in the level of consumption of basic food products. Along with this, new problems of such a nature have appeared, such as the diversion of significant budgetary funds to address the issues of the agricultural business to create complete food chicks of the completed cycle without the participation of international partners, restrictions on the development of world-class technical and technological innovations, the removal of new trends from the development of the global economy in robotization and digitalization of production processes, a decrease in the competitiveness of products in the global food market. All this undoubtedly shows the urgency of the problem of choosing priority strategic directions for the further development of the agricultural sector of the economy, which makes it necessary to further study the problems of self-provision with food, determine the directions for the development of the import substitution policy with the subsequent achievement of food security and increase the export potential of the agroindustrial complex of the country.

\section{Materials and Methods}

The theoretical and methodological basis of the study is the work of Russian and foreign scientists on the

\footnotetext{
Corresponding author: fn1973@mail.ru
} 
problems of ensuring food security, strategies for the development of the agri-food complex, regulatory and legislative acts of the Russian Federation on the regulation of agri-food policy, materials of international and all-Russian scientific and practical conferences dedicated to the development of agriculture. The general methodological basis of the research is system analysis. The extensive material and the variety of their content have caused the need to use various approaches, methods, and techniques of scientific research within the framework of system analysis, such as constructive, deterministic, retrospective, dynamic, and statistical. During the study, methods were used to reveal the development trends of agri-food policy and the peculiarities of their manifestation: monographic, abstract-logical, computational-constructive, economic and statistical, analogies. Official data of the Federal State Statistics Service of the Russian Federation, the Ministry of Agriculture of the Russian Federation, data obtained during the author's analysis and calculations were used as an information base for the study.

\section{Results}

The implementation of the strategy of self-sufficiency in food for the population of our country can be achieved only with an increase in the production of agricultural products, raw materials, and foodstuffs in all constituent entities of the Russian Federation. An analysis of the level of development of the agrarian sector of the economy over the past three years showed that the growth rate of the value indicators of the volume of production in comparable prices in agriculture in 2019 compared to 2017 reached $103.8 \%$, which means that the indicators established The State Program [3] exceeds the target by 1 percentage point (hereinafter - pp). Although in 2018 there was a slight decrease by $0.2 \%$ in the growth rate of agricultural production. The fulfillment of the planned values of the program is the main indicator of the implementation of the agrarian development program of the country, which is provided for by the policy of the government of the country to achieve import substitution of basic food products. The increase in crop production in general for all categories of producers in 2019 compared to 2017 amounted to $4.5 \%$, which exceeds the indicative value set in the program by 2.2 percentage points. The natural and climatic conditions of 2019 have recently been the most successful for farmers, contributing to growing and harvesting a large volume of production for the main types of crops, often exceeding the record achievements of recent times in some branches of crop production. Along with this, although the growth rates of livestock production increased in 2019 compared to 2017 within the range of $102.7 \%$, the value of the planned indicator remained unfulfilled by 0.8 p.p., which can be assessed as one of the constraining factors of sustainable agricultural growth. households [4, 5]. The reason for this phenomenon was the reduction in the volume of production of certain types of livestock products. From the standpoint of strengthening sustainable balanced growth of all sectors of agriculture, such a ratio of the growth rates of crop and livestock production is extremely undesirable since the sale of crop production in its original form is always low profitable for business in the domestic agricultural market. Therefore, it is desirable to sell crop production through livestock products by increasing the livestock and increasing productivity, using the growing potential of crop production in the form of grain fodder and fodder crops $[6,7]$.

The growing potential for the volume of agricultural production subsequently led to an increase in the food production index in 2019 compared to 2017 by 10 p.p. and exceed the targets of the State Program by $3.9 \%$. The level of profitability of production and economic activity of agricultural organizations, considering the number of state subsidies, increased over the past three years by 2.6 percentage points, did not reach the planned value by $8.7 \%$. The general level of profitability of $14.6 \%$ for modern agricultural organizations is not sufficient for the implementation of expanded reproduction, the more intensive modernization of agricultural production is required everywhere [8].

Modernization and technical re-equipment of the agrarian sector of the economy, considering its starting position and the socio-economic significance of the results and development prospects, requires large investments. The volume of investments in fixed assets in the agro-industrial complex has increased by 135.1 billion rubles over the past four years. at actual prices or by $23.1 \%$ in a progressively increasing order. But this process is more and more shifted onto the shoulders of the agricultural producers themselves. The share of the federal budget in the development of fixed capital of the agro-industrial complex is only $0.1 \%$, and the share of funds from the budgets of the constituent entities of the Russian Federation in this process is $0.7 \%$ [9].

It should be noted that the share of borrowed funds is increasing from year to year, which indicates a reduction in the ability of enterprises of the agro-industrial complex to carry out expanded reproduction on their own. It is known that borrowed funds must be returned with interest. The more borrowed funds are involved in circulation, the more difficult it will be to return them, they will grow like a snowball, and soon, commodity producers will be forced to withdraw active capital from circulation to repay debts and limit funds for further development, which can increase in multiples in connection with the upcoming digitalization of the rural economy and the automation of production processes. The commissioning of production facilities is carried out in all branches of agriculture.

The largest renovation of premises for cattle was carried out in 2017, 275.1 thousand cattle stalls were put into operation in other years, the pace of commissioning is accelerating at approximately the same size. The same picture is also observed in pig breeding. This can be explained by the fact that after the announcement of sanctions on the part of Western countries, an import substitution program was adopted, and the construction of buildings started after that could be ready for 
commissioning in one and a half to two years. Considering the weak position of sheep breeding, the pace of construction and commissioning of premises for this industry is increasing. For four years, the rates have grown 3.7 times. Premises for poultry farming are being built at an accelerated pace. For the egg direction, the rate increased 1.5 times, for the meat direction 4.5 times. Poultry farming is developing at a high rate not only to meet domestic needs but also to supply poultry products for export [10]. In connection with the development of animal husbandry, special attention is paid to increasing the capacity of silage and haylage facilities and to increasing the capacity of simultaneous storage of potatoes, vegetables, and fruits. Along with production facilities, capacities in the processing sector are also being commissioned (Table 1).

Table 1. Commissioning of production facilities in the processing industries of the agro-industrial complex [11]

\begin{tabular}{|c|c|c|c|c|}
\hline \multirow{2}{*}{ Indicators } & \multicolumn{4}{|c|}{ Years } \\
\cline { 2 - 5 } & $\mathbf{2 0 1 6}$ & $\mathbf{2 0 1 7}$ & $\mathbf{2 0 1 8}$ & $\mathbf{2 0 1 9}$ \\
\hline Production capacity per shift: & & & & \\
\hline meat, t & 452.1 & 82.4 & 353.3 & 112.2 \\
\hline whole milk products, t & 323.6 & 466.3 & 259.6 & 226.2 \\
\hline $\begin{array}{c}\text { Mills, tons of grain processing } \\
\text { per day }\end{array}$ & 58.0 & 160.0 & 1524.0 & - \\
\hline Feed mills, tons of feed per day & 2540.0 & 1355.0 & 1056.8 & 665.5 \\
\hline
\end{tabular}

Table 2. Production of food products, flour and cereals and feed industry, thousand tons [12]

\begin{tabular}{|c|c|c|c|}
\hline Indicators & $\mathbf{2 0 1 8}$ & $\mathbf{2 0 1 9}$ & $\begin{array}{c}\mathbf{2 0 1 9} \text { to } \\
\text { Meat and offal }\end{array}$ \\
\hline $\begin{array}{c}\text { Sausage products, including } \\
\text { sausage products for baby food }\end{array}$ & 2282.1 & 2282.1 & 100.0 \\
\hline $\begin{array}{c}\text { Semi-finished products meat, meat- } \\
\text { containing, chilled, frozen }\end{array}$ & 3276.0 & 3657.4 & 111.6 \\
\hline $\begin{array}{c}\text { Canned meat (meat-containing), } \\
\text { including canned food for baby } \\
\text { food, mub }\end{array}$ & 602.8 & 667.9 & 110.8 \\
\hline Butter & 266.7 & 269.8 & 101.2 \\
\hline $\begin{array}{c}\text { Processed liquid milk, including } \\
\text { milk for baby food }\end{array}$ & 5466.2 & 5425.4 & 99.3 \\
\hline $\begin{array}{c}\text { Cheese and dairy products made } \\
\text { using cheese technology }\end{array}$ & 673.0 & 721.0 & 107.1 \\
\hline $\begin{array}{c}\text { Powdered milk and cream, freeze- } \\
\text { dried }\end{array}$ & 133.3 & 154.8 & 116.1 \\
\hline $\begin{array}{c}\text { Vegetable oils and their fractions, } \\
\text { unrefined }\end{array}$ & 5950.2 & 6778.5 & 113.9 \\
\hline Mayonnaise and sauces & 866.1 & 852.8 & 98.5 \\
\hline White beet sugar & 6272.7 & 7264.4 & 115.8 \\
\hline $\begin{array}{c}\text { Canned fruits and vegetables - } \\
\text { total, mub }\end{array}$ & 9837.8 & 9656.2 & 98.2 \\
\hline Processed and canned potatoes & 245.0 & 309.5 & 126.3 \\
\hline Confectionery & 3913.8 & 4015.1 & 102.6 \\
\hline $\begin{array}{c}\text { Pasta, couscous and similar flour } \\
\text { products }\end{array}$ & 1414.6 & 1434.9 & 101.4 \\
\hline Compound feed, million tons & 39.2 & 30.4 & 104.1 \\
\hline
\end{tabular}

There is a steady increase in capacities for the primary processing of meat and milk. A large increase in the capacity of mill enterprises for processing grain and feed mills, which once again confirms the position on the awareness by agricultural producers of the benefits of selling plant products in processed form or turning them into livestock products, developing the feed industry (Table 2).

The data in Table 2 indicate an increase in the growth rates of the capacities of enterprises for the processing and production of food products, flour-grinding cereals, and the feed industry. For all types of products, production growth is observed in 2019 compared to 2018.

To ensure sustainable development of the agricultural business in the Russian Federation, the country's agroindustrial complex has an ambitious task - to increase the export of products and foodstuffs to $\$ 45$ billion by 2025, which is a fundamental position in the development and implementation of the state program and its subprograms. This position is since the results of the development of the national economy directly depend on the foreign economic activity of the subjects of the agricultural business to increase the export of food and agricultural raw materials. In this regard, improving the activities of agricultural business entities to increase exports is recognized as one of the priority areas. The reason for this is that the export potential and active foreign economic activity of agrarian business entities act as a catalyst in regulating the equilibrium and balance in the organization of international trade in the country.

Table 3. Export of the main types of goods of the agroindustrial complex of Russia, thousand tons [13]

\begin{tabular}{|c|c|c|c|c|}
\hline Indicators & $\mathbf{2 0 1 7}$ & $\mathbf{2 0 1 8}$ & $\mathbf{2 0 1 9}$ & $\begin{array}{c}\mathbf{2 0 1 9} \text { to } \\
\mathbf{2 0 1 8 ,} \%\end{array}$ \\
\hline $\begin{array}{c}\text { Food products and } \\
\text { agricultural raw } \\
\text { materials, USD billion }\end{array}$ & 21.6 & 25.8 & 25.8 & 100.0 \\
\hline Meat & 30.4 & 50.3 & 78.2 & 155.4 \\
\hline Poultry & 163.7 & 186.0 & 210.9 & 113.4 \\
\hline Milk & 63.2 & 53.3 & 460 & 864 \\
\hline Butter & 3.6 & 3.4 & 2.8 & 84.3 \\
\hline Sunflower oil & 2326.9 & 2109.5 & 3098.1 & 146.9 \\
\hline Cereal crops & 43230.4 & 54895.9 & 39482.5 & 71.9 \\
\hline Flour and cereals & 250.3 & 305.0 & 368.6 & 109.6 \\
\hline Oilseeds & 1737.4 & 2087.2 & 2721.9 & 130.4 \\
\hline Sugar & 559.8 & 387.5 & 687.0 & 177.3 \\
\hline Wool & 11.3 & 10.7 & 4.8 & 45.1 \\
\hline
\end{tabular}

Analysis of the indicators in Table 3 gives grounds to assert that the main commodity positions in the structure of agricultural exports are cereals, oilseeds, and sunflower oil. The main export destinations are countries such as China, Turkey, Kazakhstan, the Republic of Korea, Egypt, Belarus, the Netherlands, and Iran. For specific types of agricultural products and products of its processing, an increase in 2019 compared to 2018 can be noted in sugar exports by $77.3 \%$, meat by $55.4 \%$, sunflower oil by $46.9 \%$, oilseeds by $30.4 \%$, poultry meat by $13.4 \%$, flour and cereals by $9.6 \%$. Along with this, there was a reduction in the volume of exports of wool by $54.9 \%$, grain crops by $28.1 \%$, butter by $15.7 \%$, milk by $13.6 \%$. Overall, exports are still inferior to imports of foodstuffs and have a negative balance of USD 4.2 billion. The main indicators of imports of basic food products to Russia are shown in Table 4. 
Table 4. Import of basic food products to Russia, thousand tons [13]

\begin{tabular}{|c|c|c|c|c|}
\hline Indicators & $\mathbf{2 0 1 7}$ & $\mathbf{2 0 1 8}$ & $\mathbf{2 0 1 9}$ & $\begin{array}{c}\mathbf{2 0 1 9} \text { to } \\
\mathbf{2 0 1 8 ,} \%\end{array}$ \\
\hline $\begin{array}{c}\text { Food products and } \\
\text { agricultural raw } \\
\text { materials, USD billion }\end{array}$ & 28.9 & 29.8 & 30.0 & 100.7 \\
\hline Meat & 646.2 & 411.2 & 383.9 & 93.3 \\
\hline Poultry & 229.6 & 222.8 & 227.5 & 102.1 \\
\hline Milk & 573.2 & 427.1 & 437.3 & 102.4 \\
\hline Butter & 99.7 & 90.7 & 119.7 & 131.9 \\
\hline Sunflower oil & 25.7 & 25.7 & 2.9 & 11.2 \\
\hline Cereal crops & 746.3 & 629.5 & 515.5 & 81.9 \\
\hline Flour and cereals & 128.6 & 89.4 & 88.3 & 98.8 \\
\hline Oilseeds & 2556.5 & 2521.4 & 2338.0 & 92.7 \\
\hline Sugar & 226.3 & 324.8 & 241.3 & 74.3 \\
\hline Wool & 5.6 & 6.7 & 6.4 & 95.9 \\
\hline
\end{tabular}

For the most part, we are still forced to import products of animal origin, while there is a reduction in the products related to crop production. The analysis of foreign economic activity showed that the subjects of agricultural business in the development of exports have significant problems associated with the lack of development of the organizational structure and forms of institutions of export activities, low competitiveness of products in terms of price, and compliance with quality standards, lack of sufficient financial resources and production potential, lack of sufficient competencies of specialized personnel, etc.

This situation hinders the development of export activities of the formations of the agrarian business, reduces the volume of exports of agricultural products in general. As noted earlier, in 2019, agricultural products in the structure of all exports of goods of the Russian Federation occupy $6 \%$ and in the commodity structure of imports, the share of food products and agricultural raw materials is $12.2 \%$ those. The structural value of imports more than doubles [10]. This means that we continue to invest in the development of the agricultural sector of such exporting countries as Belarus, China, Brazil, Germany, Turkey, Ecuador, Italy.

Table 5. Self-sufficiency in basic food products, $\%[11,13]$

\begin{tabular}{|c|c|c|c|c|c|c|c|}
\hline \multirow{2}{*}{ Indicators } & \multicolumn{7}{|c|}{ Years } \\
\cline { 2 - 9 } & $\mathbf{2 0 1 4}$ & $\mathbf{2 0 1 5}$ & $\mathbf{2 0 1 6}$ & $\mathbf{2 0 1 7}$ & $\mathbf{2 0 1 8}$ & \multicolumn{2}{|c|}{$\mathbf{2 0 1 9}$} \\
\hline Corn & 153.8 & 149.1 & 160 & 170.6 & 147.2 & 95 & 155.5 \\
\hline Vegetable oil & 143.1 & 125.5 & 142.6 & 153.5 & 157.3 & 90 & 175.9 \\
\hline $\begin{array}{c}\text { Sugar made } \\
\text { from sugar beet }\end{array}$ & 83.8 & 89.9 & 101.5 & 115.1 & 108 & 90 & 125.4 \\
\hline Potatoes & 98 & 102.1 & 93.2 & 91.1 & 95.3 & 95 & 94.9 \\
\hline $\begin{array}{c}\text { Milk and dairy } \\
\text { products (in } \\
\text { terms of milk) }\end{array}$ & 78.1 & 79.9 & 80.7 & 82.3 & 83.9 & 90 & 84.4 \\
\hline $\begin{array}{c}\text { Meat and meat } \\
\text { products (in } \\
\text { terms of meat) }\end{array}$ & 82.8 & 88.7 & 90.6 & 93.5 & 95.7 & 85 & 96.7 \\
\hline $\begin{array}{c}\text { Vegetables and } \\
\text { melons }\end{array}$ & 84.1 & 86.8 & 87.4 & 87.6 & 87.2 & 90 & 88.4 \\
\hline $\begin{array}{c}\text { Fruits and } \\
\text { berries }\end{array}$ & 32.5 & 32.5 & 36.5 & 33.1 & 38.8 & 60 & 39.5 \\
\hline
\end{tabular}

Food security is defined as the level of selfsufficiency in percent and is calculated as the ratio of the volume of domestic production of agricultural products, raw materials, and foodstuffs to the volume of their domestic consumption. After the announcement of sanctions against Russia by Western European countries and the United States, agriculture and the processing industry were tasked with providing the country's population with products of their production at prices affordable for the bulk of consumers. As in all cases of history, Russian agriculture and the agro-industrial complex with dignity got out of this situation, in the most difficult conditions of limited material, technical, and labor resources, in a short period they reached the set level of self-sufficiency in basic foodstuffs (Table 5).

Table 5 shows that in 2019 the threshold values of food independence (self-sufficiency) of the Russian Federation were reached or exceeded: for grain $155.5 \%$, which is 1.6 times higher than the threshold value (at least $95 \%$ ) established by the Food Security Doctrine. (+8.3 p.p. by 2018); sugar $-125.4 \%$, which is 1.4 times higher than the threshold value (not less than $90 \%$ ) (+ 17.4 pp by 2018$)$; vegetable oil - $175.9 \%$, which is almost 2 times higher than the threshold value (at least $90 \%)(+18.6$ pp by 2018); meat and meat products $-96.7 \%$, which is 11.7 p.p. above the threshold value (at least $85 \%)(+1$ p.p. by 2018). Selfsufficiency remains below the threshold values of the Doctrine of Food Security: for milk and dairy products $84.4 \%$, which is 5.6 percentage points. below the threshold (at least $90 \%$ ) (+0.5 p.p. by 2018); vegetables and melons $-88.4 \%$, up 1.6 p.p. below the threshold (at least $90 \%)(+1.2$ p.p. by 2018$)$; fruits and berries $39.5 \%$, which is 1.5 times lower than the threshold value (at least $60 \%)(+0.7$ pp by 2018) $[13,14]$. Selfsufficiency in potatoes remained at the level of the last year $-94.9 \%$, which is by 0.1 percentage points. below the threshold value (not less than $95 \%$ ). Assessment of the level of self-sufficiency in basic food products shows the compliance of indicators with their criterion values for ensuring food security. The agrarian policy on import substitution, pursued after 2014, contributed to the growth of agricultural production and the development of processing industry enterprises. Ultimately, by 2019, a positive trend has been achieved in almost all major food groups. At the same time, problems of self-sufficiency persist in milk and dairy products, fruits, and berries. The average per capita consumption of dairy products in 2019 was $72 \%$ of the rational consumption of food products that meet modern requirements for a healthy diet, the consumption of fruits and berries $-62 \%$.

\section{Conclusion}

After the announcement by Western European countries and the United States of sanctions against Russia, agriculture and the processing industry were tasked with providing the country's population with products of their production at prices affordable for the bulk of consumers. As in all cases of history, Russian agriculture and the agro-industrial complex with dignity got out of 
this situation, in conditions of limited material, technical, and labor resources, in a short period they reached the set level of self-sufficiency in basic foodstuffs. Positive trends in the agri-food sector as a result of the implementation of the import-substituting development strategy made it possible to switch to an export-oriented strategy. The formation of a system of measures of state regulation and support for the sectors of the agri-food complex stimulated the growth of the competitiveness of national commodity producers in the food market and a significant increase in the volume of exports of agricultural products and food, and the expansion of its range. However, modern external and internal risks and challenges require adjusting the main directions of development of the agri-food complex in Russia, justifying the priorities of state regulation of the food market, have shown the need to shift the focus towards increasing the reliability of providing essential goods, increasing self-sufficiency in basic food products and balance of the food markets.

\section{References}

1. D.F. Khafizov, Features of the current stage of development of the multi-structure, Bull. of Kazan State Agrar. Univ., 3, 157-161 (2018)

2. D.I. Fayzrakhmanov, Current state and problems of agricultural development in the context of Russia's membership in the WTO, Bull. of Kazan State Agrar. Univ., 2, 58-64 (2013)

3. State program for the development of agriculture and regulation of markets for agricultural products, raw materials and food for 2013-2020 (Moscow, 2012), 204 p.

4. F.N. Avkhadiev, Increasing the sustainability of grain production (based on the materials of the Republic of Tatarstan), Bull. of Kazan State Agrar.Univ., 4, 104-108 (2016)

5. A.R. Battalova, R.S Tukhvatullin, Priority areas of development of agricultural entrepreneurship in the regions of the Russian Federation, Int. J. on Emer. Technol., 10(2), 133-136 (2019)

6. D.I. Fayzrakhmanov, O.V. Kirillova, The main directions of support for the agro-industrial complex of Russia in the conditions of the WTO, Bull. of Kazan State Agrar. Univ., 4, 28-30 (2015)

7. D.F. Khafizov, Issues of the development of small businesses and cooperation in rural areas, Bull. of Kazan State Agrar. Univ., 1, 138-144 (2019)

8. L.V. Mikhailova, Methodological features of planning the development of small businesses in agriculture, Competit. in the global world: econ., sci., technol., 7 (part 4), 100-103 (2017)

9. Federal State Statistics Service of the Russian Federation, Retrieved from: http: www.gks.ru

10. F.N. Mukhametgaliev, L.F. Sitdikova, F.F. Mukhametgalieva et al., Trends in the formation of the current agrifood policy of Russia, Stud. on Russ. Econ. Developm., 30(2), 162-165 (2019)

11. On the progress and results of the implementation in 2019 of the state programs for the development of agriculture and regulation of markets for agricultural products, raw materials and food, National report, Retrieved from: https mcx.gov.ru upload iblock 98a 98af7d467b718d07d5f138d4fe96eb6d.pdf2019_992_June.pdf

12. Agriculture of Russia (Rosinformagrotech, Moscow, 2020), p. 53

13. Balances of food resources, Retrieved from: http: old.gks.ruwpswcmconnect rosstat_mainrosstatrustatisticsenterpriseeconomy

14. Doctrine of food security of the Russian Federation: approved, By the Decree of the President of the Russian Federation of 21 January 2020, no. 20, Retrieved from: http: www.consultant. rudocumentcons_doc_LAW_343386 